\title{
26th International Conference of the Red Cross and Red Crescent
}

Geneva, 3-7 December 1995

\section{PROVISIONAL ANNOTATED AGENDA}

\section{OPENING CEREMONY}

\section{FIRST PLENARY MEETING}

1. Election of the Chairman, Vice-Chairmen, Secretary-General and two Assistant Secretaries General of the Conference

In conformity with Rule 15 of the Rules of Procedure, the first plenary meeting will elect the officers of the Conference on the proposal of the Council of Delegates.

2. Humanitarian challenges on the eve of the twenty-first century:

2.1 Keynote address by the President of the International Committee of the Red Cross

2.2 Keynote address by the President of the International Federation of Red Cross and Red Crescent Societies

3. Appointment of the Conference Commissions and adoption of their respective agendas:

Commission I: War victims and respect for international humanitarian law

Commission II: Humanitarian values and response to crises

\section{MEETINGS OF THE COMMISSIONS}

A. COMMISSION I: War victims and respect for international humanitarian law

1. Election of the Chairman, the Vice-Chairmen, the rapporteurs and the members of the Drafting Committee 


\section{International humanitarian law: from law to action - Report on the follow-up to the International Conference for the Protection of War Victims}

On the initiative of the Swiss government, an International Conference for the Protection of War Victims was held from 30 August to 1 September 1993. The States present at the Conference expressed their refusal to accept the inevitability of serious and large-scale violations of international humanitarian law, which cause suffering, destruction, destitution and death, especially among the civilian population.

At the request of the Conference, the Swiss government then brought together an Intergovernmental Group of Experts open to all States. The group adopted by consensus a series of practical recommendations aimed at promoting full respect for international humanitarian law. These recommendations, which were forwarded to the States, will be submitted to the International Conference by the Chairman of the Group of Experts on behalf of the Swiss government. A supplementary document will be provided, indicating ways in which the various components of the International Red Cross and Red Crescent Movement could contribute effectively to implementing the recommendations.

A draft resolution concerning the recommendations will also be submitted to the Conference. It will include proposals for action on the recommendations that require specific measures of implementation and application.

\section{Protection of the civilian population in wartime}

The most acute problems that have arisen in recent conflicts with regard to the protection of the civilian population concern above all women and children. Countless acts of violence, including rape, have been committed against women. These acts must be considered as war crimes in accordance with international humanitarian law. Awareness of the situation of women in war must be heightened so that measures can be adopted, in addition to the general provisions which already exist for the protection of civilians, to increase protection specifically for women. Children are also a highly vulnerable group in armed conflicts. Often left to their own devices, many are recruited or volunteer to become soldiers. Measures must also be adopted in this area, including ways of providing children with more support and facilitating their reintegration in society.

Among the most serious problems arising in connection with armed conflict and the protection of the environment are the use of starvation 
and the prevention of access to, or the contamination of, water supplies as methods of warfare. The widespread use of landmines, which cause untold suffering among the civilian population, is another serious problem. Special attention should therefore be focused on examining the results of the Review Conference of the 1980 United Nations Weapons Convention and on discussing various measures that could be taken to fight this scourge.

A report will be submitted that includes an overview of each of these problems, a brief reminder of the applicable law in force, a summary of the activities of the various components of the International Red Cross and Red Crescent Movement and proposals aimed at increasing the protection afforded war victims.

A draft resolution containing these proposals, in particular, will be submitted to the International Conference.

\section{Any other business}

\section{B. COMMISSION II: Humanitarian values and response to crises}

\section{Election of the Chairman, the Vice-Chairmen, the rapporteurs and the members of the Drafting Committee}

\section{Principles of international humanitarian assistance and protection}

The International Red Cross and Red Crescent Movement, by addressing the needs of the most vulnerable groups worldwide, advocates and acts upon its founding values and principles. This agenda item concentrates on various aspects of humanitarian assistance, in particular the Movement's response to the plight of refugees and internally displaced persons, and the ethical principles and professional standards which the Movement believes must be applied during humanitarian assistance operations.

A background document on recent international developments affecting humanitarian assistance will, inter alia, examine the Movement's concern with preventing and mitigating suffering during humanitarian crises and with improving both the efficiency and effectiveness of humanitarian assistance and protection. The document will also explore the relationship between, on the one hand, appropriate diplomatic and political action by States and international institutions and, on the other hand, the need to preserve a neutral and impartial environment in which humanitarian action can take place. 
A draft resolution will include a number of recommendations specifying the Movement's expectations of governments, in particular with a view to preserving the independence of its action. Endorsement will be sought for the newly revised "Principles and Rules for Red Cross and Red Crescent Disaster Relief" and for the "Code of Conduct for the International Red Cross and Red Crescent Movement and NGOs in Disaster Relief".

\section{Strengthening the Movement's capacity to assist and protect the most vulnerable groups}

At the national and local levels, commitment to the Movement's principles and values is demonstrated and advocated in the day-to-day programmes of the National Red Cross and Red Crescent Societies on behalf of the most vulnerable groups in their countries. To function as effective, independent auxiliaries to their governments in emergency situations and in providing community services, the National Societies must have strong and clear structures and mandates, and the necessary resources.

A background document will outline priorities for the institutional and operational development of National Societies. These include strengthening global and regional networking, upholding and advocating the characteristics of a well-functioning National Society and reviewing the statutes of National Societies with a view to preserving their integrity.

A draft resolution will, inter alia, call on governments to confirm the mandate of the National Societies as auxiliaries able to fulfil their humanitarian mission within their communities in accordance with the Movement's principles and values. It will also urge governments to renew their commitment to supporting National Society development, structures, services and disaster preparedness activities.

\section{Any other business}

\section{SECOND AND SUBSEQUENT PLENARY MEETINGS}

\section{Election of the members of the Standing Commission}

The Standing Commission of the Red Cross and Red Crescent will comprise nine members, namely:

(a) five members of different National Societies, each elected in a personal capacity; 
(b) two representatives of the International Committee of the Red Cross, one of whom shall be the President;

(c) two representatives of the International Federation of Red Cross and Red Crescent Societies, one of whom shall be the President.

In accordance with Rule 21 of the Movement's Rules of Procedure, nominations for the Standing Commission must be delivered in closed envelopes, with the curriculum vitae of each candidate, to the Chairman of the Bureau of the International Conference, 48 hours before the opening of the meeting in which the election is to take place. The proposals for candidates should therefore reach the Chairman of the Bureau, who is also the Chairman of the Conference, by 5 December 1995 at 9 a.m.

The curriculum vitae of each candidate must be circulated at least 24 hours before that meeting and should therefore be made available by 6 December 1995 at 9 a.m.

It is to be noted that personal qualities and the principle of fair geographical distribution should be taken into account.

\section{Report of Commission I and adoption of resolutions}

\section{Report of Commission II and adoption of resolutions}

\section{Any other business}

Amendment to the Statutes and the Rules of Procedure of the Movement

In 1991, the 8th Session of the General Assembly of the (then) League of Red Cross and Red Crescent Societies decided that the new name of the organization should be the "International Federation of Red Cross and Red Crescent Societies". With a view to amending the Statutes and the Rules of Procedure of the Movement to include the new name of the organization, all proposals regarding the change of name were circulated to all the members of the 26th International Conference, which was due to, but did not, take place in Budapest in 1991. Consequently, the International Federation proposes that the 26th International Conference amend the Statutes and the Rules of Procedure of the Movement in order to bring them into harmony with the decision of the International Federation's General Assembly referred to above (see Annex). 


\section{Place and date of the 27th International Conference}

NotE:

Owing to the limited time available for discussion in the Commissions, written reports will be submitted to the participants under item (4) Any other business on the following subjects:

- Report of the Chairman of the Standing Commission;

- Report of the Council of Delegates;

- Report of the Joint Commission for the Empress Shôken Fund;

- Follow-up to resolutions of the 25th International Conference.

Geneva, 31 May 1995

\section{ANNEX \\ Amendment to the Statutes and the Rules of Procedure of the Movement}

In 1991, the 8th Session of the General Assembly of the (then) League of Red Cross and Red Crescent Societies decided that the new name of the organization should be the "International Federation of Red Cross and Red Crescent Societies". With a view to amending the Statutes and the Rules of Procedure of the Movement to include the new name of the organization, all proposals regarding the change of name were circulated to all the members of the 26th International Conference, which was due to, but did not, take place in Budapest in 1991. Consequently, the International Federation proposes that the 26th International Conference amend the Statutes and the Rules of Procedure of the Movement in order to bring them into harmony with the decision of the International Federation's General Assembly referred to above.

Amendment proposed by the International Federation of Red Cross and Red Crescent Societies relating to the change of the name of the League

\section{Preamble}

Present text:

"The International Conference of the Red Cross and Red Crescent, 
Proclaims that the National Red Cross and Red Crescent Societies, the International Committee of the Red Cross and the League of Red Cross and Red Crescent Societies..."

\section{Proposed text:}

"The International Conference of the Red Cross and Red Crescent,

Proclaims that the National Red Cross and Red Crescent Societies, the International Committee of the Red Cross and the International Federation of Red Cross and Red Crescent Societies..."

\section{General provisions}

\section{Article 1: Definition}

\section{Present text:}

"1. The International Red Cross and Red Crescent Movement (hereinafter called "the Movement") is composed of the National Red Cross and Red Crescent Societies recognized in accordance with Article 4 (hereinafter called "National Societies"), of the International Committee of the Red Cross (hereinafter called "the International Committee") and of the League of Red Cross and Red Crescent Societies (hereinafter called "the League")."

Proposed text:

"1. The International Red Cross and Red Crescent Movement (hereinafter called "the Movement") is composed of the National Red Cross and Red Crescent Societies recognized in accordance with Article 4 (hereinafter called "National Societies"), of the International Committee of the Red Cross (hereinafter called "the Intemational Committee") and of the International Federation of Red Cross and Red Crescent Societies (hereinafter called "the Federation")."

\section{Components of the Movement}

\section{Present text:}

\section{"Article 6: The League of Red Cross and Red Crescent Societies}

1. The League is the International Federation of the National Red Cross and Red Crescent Societies. It acts under its own Constitution with all rights and obligations of a corporate body with a legal personality.

2. The League is..." 


\section{Proposed text:}

"Article 6: The International Federation of Red Cross and Red Crescent Societies

1. The International Federation of Red Cross and Red Crescent Societies comprises the National Red Cross and Red Crescent Societies. It acts...

2. The Federation is..."

(rest unchanged)

All relevant articles of the Statutes and of the Rules of Procedure of the International Red Cross and Red Crescent Movement shall be amended accordingly. 